\title{
AKTIVITAS ANTIOKSIDAN EKSTRAK METANOL Gracilaria $s p$. DAN Ulva $s p$. DARI PANTAI SAYANG HEULANG
}

\author{
Oleh : \\ Windy Widowaty \\ Yopi Setiawan \\ Wildan Wibawa Perdana \\ Program Studi Teknologi Pangan, Universitas Al - Ghifari \\ Jl. Cisaranten Kulon No. 140, Bandung \\ *E-mail corresponding: windy.widowaty@gmail.com
}

\begin{abstract}
Abstrak
Rumput laut atau makro alga merupakan sudah sejak lama di Indonesia dikenal sebagai bahan makanan tambahan, sayuran dan obat tradisional. Gracilaria sp mengandung banyak metabolit seperti : karoten, terpenoid, xantofil, klorofil, vitamin, dan beberapa senyawa antioksidan sementara senyawa bioaktif tersebut terkandung pada Ulva sp yang disebut dengan istilah ulvan, yaitu Sulfated Polysaccharide. Kedua jenis rumput laut tersebut banyak ditemukan di pantai Sayang Heulang, Garut Jawa Barat. Antioksidan yang terkandung dalam Ulva sp bersifat alami, tidak seperti antioksidan sintetis, seperti Butylated Hydroxyanisole (BHA) dan Butylated Hydroxytoluene (BHT) yang dapat mengganggu fungsi hati dan bersifat karsinogenik. Radikal bebas (free radical) merupakan salah satu bentuk senyawa dengan memiliki elektron yang tidak berpasangan dimana senyawa tersebut sangat reaktif mencari pasangan elektron dari molekul lain yang ada disekitarnya agar menstabilkan diri. Antioksidan ini berfungsi untuk membantu melindungi tubuh dari serangan radikal bebas dan meredam dampak negatifnya. Selain daripada itu, antioksidan pun dapat berkomponen untuk melindungi sel dari kerusakan yang diakibatkan oleh reaktif oksigen spesies seperti oksigen singlet, superoksida, radikal hidroksil, radikal peroksil dan peroksi nitrit. Pada penelitian ini dilakukan pengujian aktivitas antioksidan dari dua jenis rumput laut yang berasal dari pantai Sayang Heulang Garut, Jawa Barat yaitu jenis Gracilaria sp dan Ulva sp dengan menggunakan metoda DPPH. Untuk mendapatkan ekstrak kasar rumput laut tersebut, maka dilakukan ekstraksi dengan metode Folch yang telah dimodifikasi (metanol : kloroform : buffer fosfat, 2:1:0,8 (v/v)). Ekstrak yang dihasilkan masing - masing diuji aktivitas antioksidanya dengan menggunakan metode DPPH. Hasil penelitian tersebut, menunjukkan bahwa ekstrak kasar Gracilaria sp dan Ulva sp memiliki aktivitas antioksidan masing - masing sebesar $221,76 \mu \mathrm{g} / \mathrm{mL}$ dan $404,73 \mu \mathrm{g} / \mathrm{mL}$.
\end{abstract}

Kata kunci: Antioksidan, Gracilaria sp, Ulva sp, DPPH.

\begin{abstract}
Seaweed or macroalgae has long been known in Indonesia as a food additive, vegetables, and traditional medicine. Gracilaria sp. contains many metabolites such as carotene, terpenoids, xanthophyll, chlorophyll, vitamins, and several antioxidant compounds but the bioactive compounds contained in Ulva sp. are called ulvan, which is a sulfated polysaccharide. Both types of seaweed are found on Sayang Heulang beach, Garut, West Java. The antioxidants contained in Ulva sp. are natural, unlike synthetic antioxidants, such as Butylated Hydroxyanisole (BHA) and Butylated Hydroxytoluene (BHT) that can interfere with liver function and are carcinogenic. Free radicals are a form of compounds that have unpaired electrons where the compound is very reactive searching for electron pairs from other molecules around it to stabilize itself. Antioxidants function to help protect the body from free radical attacks and reduce their negative effects.
\end{abstract}


Antioxidants are components that can protect cells from damage caused by reactive oxygen species such as singlet oxygen, superoxide, bydroxyl radicals, peroxyl radicals, and peroxynitrite. In this study, the antioxidant activity of two types of seaweed from Sayang Heulang Garut beach, West Java will be tested, namely the types of Gracilaria sp and Ulva sp. Using the DPPH method. To obtain crude seaweed extract, extraction was carried out using the modified Folch method (methanol: chloroform: phosphate buffer, 2: 1: 0.8 $(v / v))$. The extracts produced were each tested for their antioxidant activity using the DPPH method. The results showed that the crude extracts of Gracilaria sp and Ulva sp had an antioxidant activity of $221.76 \mu \mathrm{g}$ / $m L$ and $404.73 \mu \mathrm{g} / \mathrm{mL}$, respectively.

Keywords : Antioxidant, Gracilaria sp, Ulva sp, DPPH. 


\section{PENDAHULUAN}

Rumput laut atau makroalga merupakan sudah sejak lama di Indonesia yang dikenal sebagai bahan makanan tambahan, sayuran dan obat tradisional. Rumput laut tersebut menghasilkan senyawa koloid yang disebut fikokoloid yaitu agar, al-gin dan karaginan. Dalam pemanfaatannya kemudian berkembang untuk kebutuhan bahan baku industri makanan, kosmetik, farmasi dan kedokteran.

Rumput laut Gracilaria adalah rumput laut yang termasuk pada kelas Rhodophyta (alga merah). Ciri dari rumput laut Gracilaria adalah memiliki bentuk talus yang membentuk rumpun tidak teratur. Gracilaria sp. mengandung banyak metabolit seperti : karoten, terpenoid, xantofil, klorofil, vitamin, dan beberapa senyawa antioksidan (Layse F. de Almeida et al., 2011).

Rumput laut Ulva merupakan nama salah satu genus yang terdapat dalam kelas Chlorophyta (alga hijau). Rumput laut Ulva sp memiliki kandungan nutrisi, diantaranya: $18,7 \%$ air, $14,9 \%$ protein, 0,04\% lemak, 50,6\% karbohidrat, dan $0,2 \%$ serat. Senyawa bioaktif tersebut terkandung pada bagian Ulva sp yang disebut dengan istilah ulvan, yang merupakan Sulfated Polysaccharide. Antioksidan yang terkandung dalam Ulva sp sifatnya alami, tidak seperti antioksidan sintetis, seperti Butylated Hydroxyanisole (BHA) dan Butylated Hydroxytoluene (BHT) yang dapat mengganggu fungsi hati dan bersifat karsinogenik (Srikong $e t$ al., 2017).

Pada penelitian ini akan dilakukan pengujian aktivitas antioksidan dari dua jenis rumput laut yang berasal dari pantai Sayang Heulang Gerut, Jawa Barat yaitu jenis Gracilaria sp. dan Ulva sp. dengan menggunakan metoda DPPH.

Antioksidan adalah komponen yang melindungi sel dari kerusakan yang ditimbulkan oleh radikal bebas. Radikal bebas didefinisikan sebagai senyawa yang sangat reaktif dalam mencari pasangan elektron dari molekul lain disekitarnya untuk menstabilkan dirinya. Beberapa penyakit akibat adanya radikal bebas yang berlebihan di dalam tubuh diantaranya adalah rusaknya makromolekul dalam sel seperti protein dan DNA (deoxyribo nucleic acid), kanker dan lainnya (Deng et al., 2011).

\section{METODE PENELITIAN}

Penelitian diawali dengan sampling rumput laut, ekstraksi dan uji aktivitas antioksidan. Metodologi penelitian dapat dijabarkan sebagai berikut:

\section{A. Tahap Persiapan Sampel}

Sampel rumput laut diambil dari pantai Sayang Heulang yang terletak di Kecamatan Pameungpeuk Kabupaten Garut Provinsi Jawa Barat. Sampel yang diambil adalah jenis Gracilaria sp. dan Ulva $s p$. yang dibedakan dari penampakan dan ciri morfologisnya. Sampel dipilih yang masih segar dan masih terdapat holfast. Rumput laut dibersihkan dari pengotor dan pasir untuk selanjutnya di bawa ke laboratorium untuk perlakuan selanjutnya.

Penelitian ini dilakukan pada bulan April-November 2020 yang bertempat di Laboratorium Penelitian Fakultas Teknologi Pertanian Universitas AlGhifari yang beralamat di Jl. Cisaranten Kulon No. 140, Bandung. Sampel yang dibawa dari pantai Sayang Heulang dibersihkan kembali dan dikeringkan di udara terbuka selama 1 jam dan dilanjutkan dikeringkan dengan menggunakan food debydrator selama 2 jam 30 menit. Rumput laut kering selanjutnya dihaluskan dengan menggunakan blender dan siap untuk diekstraksi.

\section{B. Ekstraksi}

Ekstraksi rumput laut tersebut dilakukan dengan metode Folch termodifikasi (Kumari et al., 2011) yang menggunakan pelarut kloroform p.a, metanol p.a, dan buffer fosfat $0,05 \mathrm{M} \mathrm{pH}$ 7,6 dengan perbandingan 2:1:0,8 (v/v). Setelah satu jam perendaman, kemudian dilakukan sentrifugasi dengan $2060 \mathrm{~g}$ selama 15 menit. Dalam pemisahan supernatan dan pelet yaitu menggunakan kertas saring. Pelet yang telah dipisahkan 
kemudian disentrifugasi lagi dan ditambahkan pelarut kloroform p.a., metanol p.a., serta buffer fosfat 0,05 M $\mathrm{pH}$ 7,6 yang perbandingannya 1:1:0,8 $(\mathrm{v} / \mathrm{v})$, sedangkan perbandingan antara sampel dengan pelarutnya yaitu 1:4 (w/v). Setelah itu dilakukan lagi pemisahan supernatan dan pelet. Langkah reekstraksi tersebut dilakukan kembali sebanyak 2 kali. Supernatan yang sudah terkumpul dari hasil sentrifugasi ditambahkan air mili-Q dengan perbandingan supernatan dan air mili-Q sebesar 9:2 (v/v). Setelah itu dilakukan sentrifugasi lagi selama 5 menit. Hasil sentrifugasi dipisahkan sehingga terbentuk ekstrak kasar yang terpisah pada fasa kloroform dan metanol untuk masing-masing sampel rumput laut. Selanjutnya dilakukan penguapan pelarut pada ekstrak kasar menggunakan rotary evaporator.

\section{Uji Aktivitas Antioksidan dengan menggunakan DPPH}

Uji aktivitas antioksidan dilakukan dengan metode penangkapan radikal bebas dengan metode DPPH (1,1diphenyl-2-picrylhidrazil) sesuai metode dari (Chan et al., 2011)dengan beberapa modifikasi. Dibuat larutan stok sampel ekstrak rumput laut dengan konsentrasi $1000 \mu \mathrm{g} / \mathrm{mL}$ dalam metanol dan dibuat pengenceran bertingkat dengan berbagai variasi konsentrasi antara $1000 \quad 0$

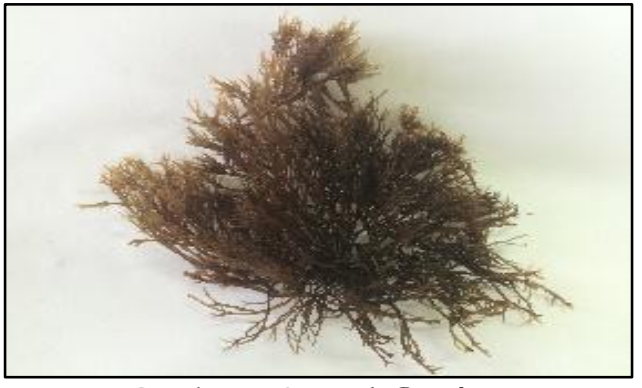

Gambar 1. Sampel Gracilaria sp.

\section{Ekstraksi}

Ekstraksi rumput laut ini dilakukan dengan metode Folch termodifikasi (Kumari et al., 2011) yang menggunakan pelarut kloroform p.a, metanol p.a, dan buffer fosfat $0,05 \mathrm{M} \mathrm{pH} \mathrm{7,6} \mathrm{dengan}$ $\mu \mathrm{g} / \mathrm{mL}$. Sampel dengan berbagai variasi konsenstrasi sebanyak $0,4 \mathrm{ml}$ ditambahkan dengan $0,8 \mathrm{ml}$ larutan DPPH 0,06 mM (3,9 mg DPPH/100 ml metanol). Larutan diinkubasi dalam ruangan gelap selama 30 menit dan setelah inkubasi diukur absorbansi pada panjang gelombang $517 \mathrm{~nm}$. Sebagai blanko digunakan akuades. Kemampuan sampel untuk menangkap radikal bebas $(\%)$ dihitung dengan menggunakan persamaan 1 berikut :

$$
\% \text { Inhibisi Radikal Bebas }=\frac{A_{\text {kontrol }}-A_{\text {sampel }}}{A_{\text {kontrol }}} \times 100 \%
$$

\section{HASIL DAN PEMBAHASAN}

Penelitian diawali dengan sampling rumput laut, ekstraksi dan uji aktivitas antioksidan. Metodologi penelitian dapat dijabarkan sebagai berikut :

\section{Tahap Persiapan Sampel}

Sampel rumput laut yang diambil dari pantai Sayang Heulang adalah jenis Gracilaria sp. dan Ulva sp. dimana masing masing rumput laut ini diambil pada kedalaman 0,75-1,00 meter dan pada sepanjang jarak 74 meter dari tepi pantai. Gambar 1 dan 2 menunjukkan sampel Gracilaria sp. dan Ulva sp. yang diambil dari pantai Sayang Heulang.

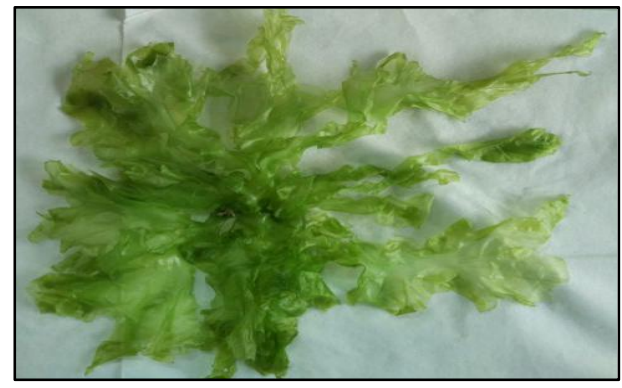

Gambar 2. Sampel Ulva sp.

perbandingan 2:1:0,8 (v/v). Hasil ekstraksi tersebut, dimodifikasi dan diperoleh ekstrak kasar metanol serta ekstrak kasar kloroform dari masing - masing sample rumput laut. 


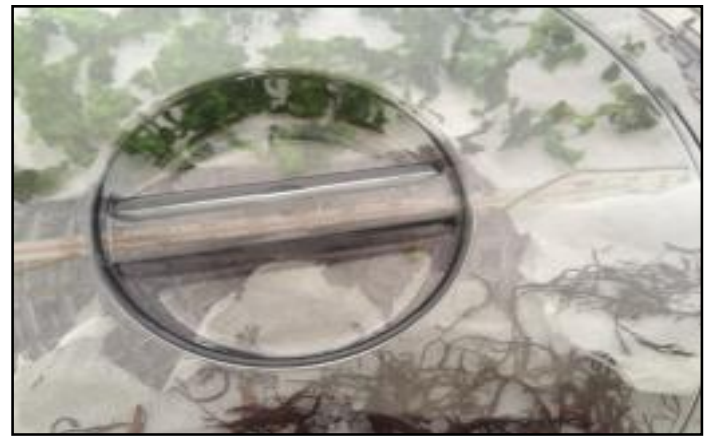

Gambar 3. Proses pengeringan rumput lau dengan menggunakan Food Debydrator.

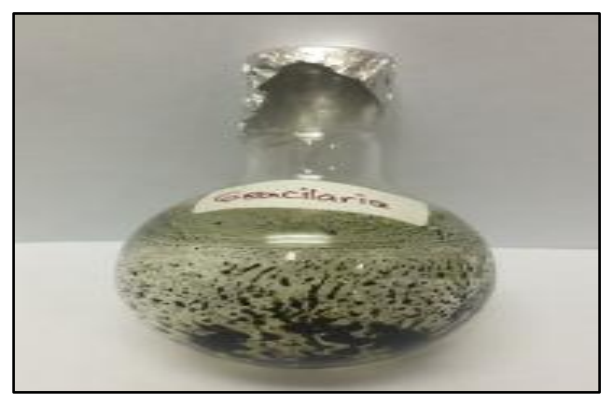

a

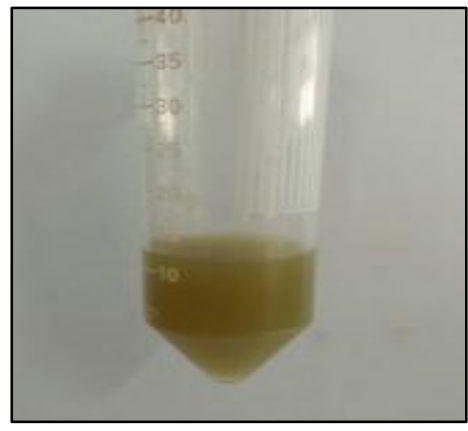

c

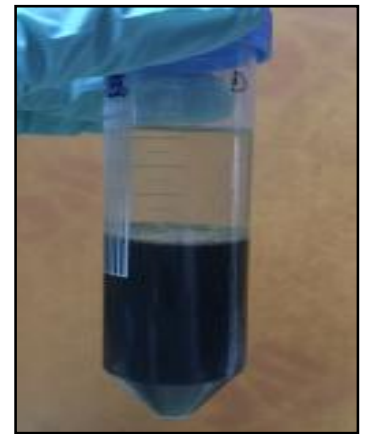

Gambar 4. Ekstraksi Rumput Laut dengan menggunakan metode Folch yang dimodifikasi.

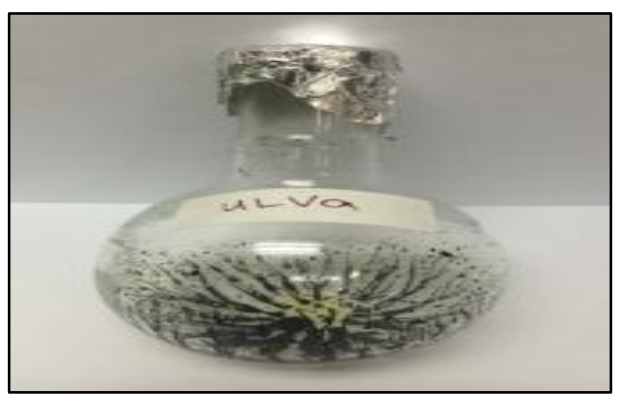

b

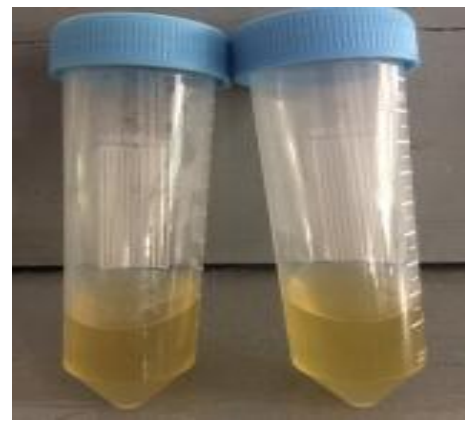

d

Gambar 5. Hasil ekstraksi yang telah dihilangkan pelarutnya (a) Ekstrak kloroform Gracilaria sp, (b) Ekstrak Kloroform Ulva sp, (c) Ekstrak Metanol Gracilaria sp, dan (d) Ekstrak Metanol Ulva sp.

\section{Uji Aktivitas Antioksidan dengan menggunakan DPPH}

Uji aktivitas antioksidan dilakukan dengan metode penangkapan radikal bebas dengan metode DPPH (1,1diphenyl-2-picrylhidrazil) sesuai metode dari Chan dkk. (2011) dengan beberapa modifikasi. Dibuat larutan stok sampel ekstrak rumput laut dengan konsentrasi $1000 \mu \mathrm{g} / \mathrm{mL}$ dalam metanol dan dibuat pengenceran bertingkat dengan berbagai variasi konsentrasi antara 1000 - 0 $\mu \mathrm{g} / \mathrm{mL}$. Sampel dengan berbagai variasi konsenstrasi sebanyak $0,4 \quad \mathrm{ml}$ ditambahkan dengan $0,8 \mathrm{ml}$ larutan
DPPH 0,06 mM (3,9 mg DPPH/100 ml metanol). Masing - masing larutan dengan berbagai konsentrasi diinkubasi dalam ruangan gelap selama 30 menit dan selanjutnya diukur absorbansi pada panjang gelombang $517 \mathrm{~nm}$. Sebagai blanko digunakan akuades.. Kemampuan sampel untuk menangkap radikal bebas (\%) dihitung dengan menggunakan persamaan 1 berikut :

$\%$ Inhibisi Radikal Bebas $=\frac{A_{\text {kontrol }}-A_{\text {sampel }}}{A_{\text {kontrol }}} \times 100 \%$

Uji aktivitas antioksidan dengan menggunakan metode DPPH menunjukkan bahwa ekstrak kasar 
Metanol sari rumput laut jenis Gracilaria sp. memiliki aktivitas antioksidan yang lebih baik dibandingkan dengan jenis Ulva sp. Hal ini ditujukkan dengan nilai $\mathrm{IC}_{50}$ dari Gracilaria sp yang lebih kecil daripada Ulva sp sebesar 221,76 $\mu \mathrm{g} / \mathrm{mL}$. Dari hasil pengukuran dapat dilihat pada Gambar 4 bahwa kedua rumput laut memiliki nilai $\mathrm{IC}_{50}$ lebih tinggi dibandingkan standar antioksidan yang dipakai yaitu asam galat $\left(\mathrm{IC}_{50}=51,17 \mu \mathrm{g} / \mathrm{mL}\right)$.

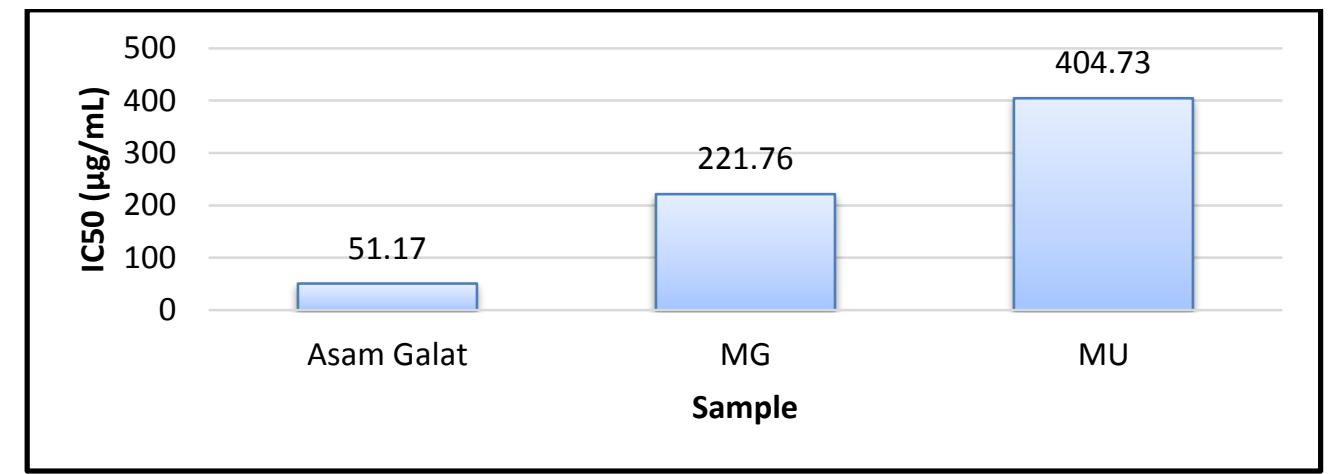

Gambar 6. Nilai IC 50 dari Asam Galat, Ekstrak Metanol Gracilaria sp. (MG), dan Ekstrak Metanol Ulva sp. (MU).

Aktivitas antioksidan berhubungan dengan kemampuan suatu senyawa bioaktif untuk mendonorkan Hidrogen (H) sehingga membentuk DPPH yang tereduksi (DPPH-H). Senyawa - senyawa golongan fenol, polifenol dan flavonoid diketahui memiliki aktivitas antioksidan dengan mendonorkan Hidrogen $(\mathrm{H})$ (Chia et al., 2015). Senyawa - senyawa polifenol dapat diekstraksi dengan menggunakan pelarut - pelarut polar seperti metanol. Metode ekstraksi dengan menggunakan kloroform dan metanol akan menghasilkan ekstrak kasar polar dan non polar dimana kloroform akan melarutkan lipid yang terdapat pada rumput laut dan metanol akan memutus ikatan protein dan menonaktifkan lipase. Penambahan air pada sistem tersebut akan mencuci bagian - bagian non lipid yang terdapat pada rumput laut. Hasil ekstraksi dengan metode ini akan didapatkan ekstrak kasar metanol yang bersifat polar dan ekstrak kasar kloroform yang bersifat non polar yang akan mempengaruhi aktivitas antioksidannya. Dari penelitian ini dapat disimpulkan sementara bahwa ektrak kasar metanol Gracilaria sp. memiliki potensi sebagai antioksidan dengan kekuatan sedang dibandingkan dengan Ulva sp.

\section{KESIMPULAN}

Dari penelitian ini dapat disimpulkan bahwa ektrak kasar metanol Gracilaria sp. memiliki potensi sebagai antioksidan dengan kekuatan sedang dibandingkan dengan Ulva sp. dengan nilai $\mathrm{IC}_{50}$ masing - masing sebesar 221,76 $\mu \mathrm{g} / \mathrm{mL}$ dan $404,73 \mu \mathrm{g} / \mathrm{mL}$.

\section{DAFTAR PUSTAKA}

Chan, EricW. C., Tie, P., Soh, E., \& Law, Y. 2011. Antioxidant and antibacterial properties of green, black, and herbal teas of Camellia sinensis. Pharmacognosy Research, 3(4):266.

https://doi.org/10.4103/09748490.89748.

Chia, Y. Y., Kanthimathi, M. S., Khoo, K. S., Rajarajeswaran, J., Cheng, H. M. dan

Yap, W. S. 2015. Antioxidant and cytotoxic activities of three species of tropical seaweeds. BMC Complementary and Alternative Medicine, 15(1). https://doi.org/10.1186/s12906015-0867-1.

Deng, J., Cheng, W., \& Yang, G. 2011. A novel antioxidant activity index (AAU) for natural products using 
the DPPH assay. Food Chemistry, 125(4), 1430-1435. https://doi.org/10.1016/j.foodche m.2010.10.031

Kumari, P., Reddy, C. R. K., \& Jha, B. 2011. Comparative evaluation and selection of a method for lipid and fatty acid extraction from macroalgae. Analytical Biochemistry, 415, 134-144. https://doi.org/10.1016/j.ab.2011. 04.010 .

Layse F. de Almeida, C., de S. Falcao, H., de M. Lima, G. R., de A. Montenegro, C., Lira, N. S., de Athayde-Filho, P. F., Rodrigues, L. C., de Souza, M. de F. V., Barbosa-
Filho, J. M., \& Batista, L. M. 2011. Bioactivities from Marine Algae of the Genus Gracilaria. International Journal of Molecular Sciences, 12, 4550-4573.

https://doi.org/10.3390/ijms1207 4550 .

Srikong, W., Bovornreungroj, N., Mittraparparthorn, P., \& Bovornreungroj, P. 2017. Antibacterial and antioxidant activities of differential solvent extractions from the green seaweed Ulva intestinalis. ScienceAsia. 43(2):88.

https://doi.org/10.2306/scienceasi a1513-1874.2017.43.088 